\title{
HAK ASASI MANUSIA DALAM ISLAM
}

\section{Hafniati}

Fakultas Agama Islam (FAI) Universitas Ibnu Chaldun (UIC) Jakarta Jl. Pemuda I Kav. 97 Rawamangun Jakarta Timur

Email: haf:ul74@gmail.com

\section{Abstract}

Human rights are fundamental rights that are inherent in human beings and cannot be eliminated by bumans, not by someone, organization or anything but purely a gift from Allah SWT. Muslims must be aware of and understand the rights they have as stated in the Koran. Al-Qur'an as the first source of law for Muslims has laid the basic foundation of buman rights and truth and justice, long before any thoughts about it arose in the world community. This can be seen in the provisions contained in the Qur'an, among others: the Right to Life, the Right to Freedom, the right to gain knowledge / education, the right to self respect and the right to possess. In the context of Indonesian-ness, Human Rights found its relevance if it was built based on the orientation of the maqasid as-syari'ah (the basic objectives of sharia), namely to realize and maintain the goodness and prosperity of society. the interests of society, this became known as mashlahah 'ammah.

\section{Abstrak}

Hak Asasi adalah hak mendasar yang melekat pada diri manusia dan tidak dapat dibilangkan oleh manusia, bukan pemberian seseorang, organisasi atau apapun melainkan murni anugerah dari Allah SWT. Umat Islam harus menyadari dan memahami tentang bak-bak yang dimilikinya sebagaimana tercantum dalam al-Quran. Al-Qur'an sebagai sumber bukum pertama bagi umat Islam telah meletakkean dasar dasar HAM serta kebenaran dan keadilan, jauh sebelum timbul pemikiran mengenai hal tersebut pada masyarakat dunia. Hal ini dapat dilibat ketentuan-ketentuan yang terdapat dalam al-Qur'an, antara 
lain:Hak Hidup, Hak untuk merdeka, hak mendapatkan ilmu/ pendidikan, hak kehormatan diri dan hak memiliki. Dalam konteks keindonesiaan, Hak Asasi Manusia menemukan relevansinya apabila dibangun berdasarkan orientasi maqasid as-syari'ah (tujuan-tujuan dasar syariab), yakni mewujudkan dan menjaga kebaikan serta kemakmuran masyarakat. kepentingan masyarakat, ini kemudian dikenal dengan sebutan mashlabah 'ammah.

Keywords: Human Rights, the Quran, Islam

\section{A. Pendahuluan}

Agama Islam adalah agama terakhir yang diturunkan oleh Allah melalui Rasulullah SAW di tengah masyarakat Quraisy yang sangat bobrok norma dan akhlaknya ketika itu.Kondisi masyarakat Arab Jahiliyah dengan tradisi perang antar suku, menganggap remeh wanita berhasil dituntaskan oleh Rasulullah SAW dengan berpedoman kepada al-Quran. Islam agama yamg mengakui persamaan hak manusia dalam penciptaan. Islam juga mengakui adanya perbedaan dalam hal-hal tertentu. Karena perbedaan merupakan sunnatullah yang menjadikan manusia saling melengkapi antara satu dengan yang lainnya.

Pengakuan, penghormatan, keadilan ${ }^{1}$ dan kerja sama adalah unsur-unsur penting dalam konsep Hak Asasi Manusia (HAM). Unsur-unsur tersebut terdapat dalam sumber Islam (Syari'ab) yaitu alQuran dan as-Sunnah. Hak asasi manusia dalam Al-Qur'an tidak disebutkan secara spesifik. Namun Al-Qur'an memuat kandungan tentang hal-hal yang prinsip dalam keberlangsungan hidup manusia, seperti: keadilan, musyawarah, saling menolong, menolak diskriminasi, menghormati kaum wanita, kejujuran, dan lain sebagainya.

Hak asasi yang ada pada manusia seperti kebebasan, persamaan, keadilan, perlindungan, dan sebagainya bukan merupakan pemberian seseorang, organisasi, atau Negara, tapi adalah anugerah

${ }^{1}$ Mahmud Syaltuth menyebutkan keadilan merupakan bagian yang sangat penting dalam sistem yang berorientasi kepada Tuhan. Dikatakannya, "Keadilan adalah sistem Allah saw. dan syari'ah-Nya". Baca Mahmud Syaltut, Islam Aqidah wa Syari'ah (Cairo: Dar al-Qalam, 1966), hlm. 453. 
Allah SWT yang sudah dibawanya sejak lahir ke alam dunia. Apabila manusia tidak memahami hak-hak yang dimilikinya maka manusia tidak dapat menjalankan tugas serta kewajibannya sebagai khalifah di muka bumi. Umat Islam harus menyadari dan memahami tentang hak-hak yang dimilikinya sebagaimana tercantum dalam al-Quran. Hal ini mungkin akibat rendahnya pendidikan atau sistem sosial politik dan budaya di tengah masyarakat. Hak Asasi Manusia sudah diatur berdasarkan atau berpedoman pada Al-Qur'an dan Hadist sebagai tuntunan hidup umatmanusia. Oleh karena itu kita harus mengetahui hak-hak kita dan selalu memperjuangkannya selama tidak mengambil atau melampui batas dari hak-hak orang lain.

\section{B. Pembahasan}

\section{Pengertian HAM (Hak Asasi Manusia)}

HAM merupakan singkatan dari Hak Asasi Manusia. Ada yang mendefinisikan: Hak Asasi Manusia adalah "Kekuasaan dan keamanan" yang dimiliki setiap individu.Hak Asasi Manusia adalah tuntunan yang secara moral bisa dibenarkan, agar seluruh manusia dapat menikmati dapt melaksanakan kebebasan mereka, harta benda mereka, dan pelayanan-pelayanan mereka yang dipandang perlu untuk mencapai harkat kemanusiaan. Hak Asasi Manusia adalah kebutuhan dasar manusia yang berupa hak-haknya, dan tanpa hakhak itu kita tidak dapat hidup layak sebagai manusia. ${ }^{2}$

Menurut istilah Hak asasi manusia adalah seperangkat hak yang melekat pada manusia sebagai makhluk Tuhan Yang Maha Esa. Hak asasi manusia merupakan anugerah yang wajib dihormati, dijunjung tinggi, dan dilindungi oleh negara, hukum, pemerintah, dan setiap orang demi kehormatan serta perlindungan harkat dan martabat manusia. Hak asasi manusia disebut hak dasar. Hak asasi manusia pada hakikatnya merupakan hak yang dimiliki manusia yang melekat (inheren) padanya karena dia adalah manusia. Manusia adalah makhluk ciptaan Tuhan dengan segala harkat dan martabatnya yang tinggi. Hal itulah yang membedakannya dengan makhluk lain. Hak asasi manusia ini sifat-sifatnya mendasar dan fundamental. Dalam

${ }^{2}$ H.A.R. Tilaar. Dimensi-dimensi Hak Asasi Manusia dalam Kurikulum Persekolahan Indonesia.PT Alumni, Bandung, 2010, hlm. 21 
pelaksanaannya mutlak diperlukan agar manusia dapat berkembang sesuai dengan harkat, martabat, dan cita-citanya.Hak ini juga dianggap universal, artinya dimiliki semua manusia tanpa membedakan bangsa, ras, agama, dan jenis kelamin.

Menurut Pasal 1 Piagam PBB, salah satu tujuan PBB adalah untuk mencapai kerja sama internasional dalam mewujudkan dan mendorong penghargaan atas hak-hak asasi manusia dan kemerdekaan yang mendasar bagi semua orang, tanpa membedakan suku, bangsa, kelamin, bahasa, maupun agama. ${ }^{3}$

Mr. Kuntjoro Purbopranoto dalam bukunya Hak Asasi Manusia dan Pancasila menyebutkan : dalam declaraation of independence America (tertanggal 4jui 1996) itu dinyatakan bahwa sekalian manusia diciptaan dalam keadaan sama bahwa manusia dikaruniai oleh Yang Maha Kuasa beberapa yang tetap dan melekat padanya (manusia) dan sebagainya. ${ }^{4}$

Dalam prisma nomor 12 tahun 1979 disebutkan : maka pada dirinya tertanam sudah hak-hak tersebut. Orang tidak memperoleh hak itu dari pemerintah, dan tak seorangpun manusia yang memberikan hak tertentu pada seorang manusia lainnya. Ia kita peroleh dari Maha Pencipta. ${ }^{5}$ Undang-Undang Nomor 39 Tahun 1999 tentang HAM disebutkan bahwa "Hak Asasi Manusia adalah seperangkat hak yang melekat pada hakekat dan keberadaan manusia sebagai makhluk Tuhan Yang Maha Esa dan merupakan anugerahNya yang wajib dihormati, dijunjung tinggi, dan dilindungi oleh negara, hukum, pemerintah dan setiap orang, demi kehormatan serta perlindungan harkat dan martabat manusia".

Hakikat Hak Asasi Manusia sendiri adalah merupakan upaya menjaga keselamatan eksistensi manusia secara utuh melalui aksi keseimbangan antara kepentingan perseorangan dengan kepentingan umum. Begitu juga upaya menghormati, melindungi, dan menjunjung tinggi Hak Asasi Manusia menjadi kewajiban dan tangung jawab

${ }^{3}$ Ibid, h. 22

${ }^{4} \mathrm{Mr}$. Kuntjoro Purbopranoto. Hak Asasi manusia dan Pancasila. Jakarta : Pradnya paramita. 1976. Hal 17

${ }^{5}$ Drs. Dalizar Putra. Hak Asasi Manusia Menurut Al-Qur'an. Jakarta : Al-Husna Zikra. 1995. Hal 32 
bersama antara individu, pemeritah (Aparatur Pemerintahan baik Sipil maupun Militer), dan negara.

Berdasarkan beberapa rumusan hak asasi manusia di atas, dapat ditarik kesimpulan tentang beberapa sisi pokok hakikat hak asasi manusia, yaitu :

a. HAM tidak perlu diberikan, dibeli ataupun diwarisi, HAM adalah bagian dari manusia secara otomatis.

b. HAM berlaku untuk semua orang tanpa memandang jenis kelamin, ras, agama, etnis, pandangan politik atau asal usul sosial, dan bangsa.

c. HAM tidak bisa dilanggar, tidak seorangpun mempunyai hak untuk membatasi atau melanggar hak orang lain. Orang tetap mempunyai HAM walaupun sebuah negara membuat hukum yang tidak melindungi atau melanggar HAM.

\section{Sejarah Lahir dan Perkembangan HAM}

Menurut para pakar HAM bahwa lahirnya HAM dimulai dengan lahirnya Piagam Magna Charta. Piagam ini menyatakan bahwa raja yang semula memiliki kekuasaan absolut (raja yang menciptakan hukum, akan tetapi ia sendiri tidak terikat dengan hukum), kekuasaan raja tersebut dibatasi dan mulai dapat diminta pertanggungjawabannya di muka hukum. Dari piagam tersebut kemudian lahir suatu doktrin bahwa raja tidak kebal hukum lagi serta bertanggung jawab kepada hukum.

Sejak lahirnya piagam ini maka dimulai babak baru bagi pelaksanaan HAM yaitu jika raja melanggar hukum ia harus diadili dan mempertanggungjawabkan kebijaksanaannya kepada parlemen. Hal ini menunjukkan bahwa sejak itu sudah mulai dinyatakan bahwa raja terikat dengan hukum dan bertanggungjawab kepada rakyat, namun kekuasaan membuat undang-undang pada masa itu lebih banyak berada di tangannya. Dengan demikian, kekuasaan raja mulai dibatasi sebagai embrio lahirnya monarki konstitusional yang intinya kekuasaan raja sebagai simbol belaka.

Pasal 21 dari piagam ini Maghna Charta menggariskan "Earls and barons shall be fined by their aqual and only in propotion to thes measure of the offence" (Para Pangeran dan Baron akan dihukum berdasarkan atas 
kesamaan, dan sesuai dengan pelanggaaran yang dilakukan) selanjutnya pada pasal 40 ditegaskan lagi “.. No one will we denny or delay righ or justice" (... tidak seorangpun menghendaki kita mengingari atau menunda tegaknya hak atau keadilan). Lahirnya Maghna Charta ini kemudian diikuti oleh perkembangan yang lebih konkrit, dengan lahirrnya Bill of Rights di Inggris pada tahun 1689.

Bersamaan dengan peristiwa tersebut timbul adagium yang intinya bahwa manusia sama di muka bumi (equality before the law). Adagium ini selanjutnya memperkuat dorongan timbulnya supremasi negara hukum dan demokrasi. Keadialan Bill of Rghs telah menghasilkan asas persamaan harus diwujudkan, betapapun berat resiko yang dihadapi, karena hak kebebasan baru dapat diwujudkan kalau ada hak persamaan.

Untuk mewujudkan asas persamaan itu maka lahirlah teori "kontrak sosial" J.J. Rosseau. Setelah itu kemudian disusul oleh Mountesqueu dengan doktrin trias politikanya yang terkenal yang mengajarkan pemisahan kekuasaan untuk mencegah tirani. Selanjutnya John Loke diInggris dan Tomas Jefferson di Amerika Serikat dengan gagasan tentang hak hak dasar kebebasan dan persamaan. ${ }^{6}$

Sejarah hak-hak asasi manusia tumbuh dan dan berkembang pada waktu hak-hak asasi manusia mulai diperhatikan dan diperjuangkan. Orang pertama yang memperhatikan hak-hak asasi manusia ini adalah tokoh-tokoh hukum alam dan dari pakar-pakar hukum alam atau dengan kata lain pakar pemikir dunia yang memberikan pengaruh besar kepada hak-hak asasi manusia adalah John Locke dan Rousseou.

Kedua tokoh inilah yang memberikan inspirasi kepada revolusi negara-negara besar untuk mencantumkan di dalam konstitusinya hak-hak asasi manusia. Untuk pertama kali dengan resmi dalam declaration of independence (Amerika) tahun 1776 atas jasa seorang seniman yang kemudian menjadi presiden USA Thomas Jefferson. Kemudian declaration of independence (Amerika) ini menjadi dasar Konstitusi Negara Amerika itu ditahun 1897.

${ }^{6}$ A. Ubaidillah, Abdul Rozak dkk,Pendidikan Kewarganegaraan (Demokrasi, HAM \& Masyarakat Madani).Penerbit IAIN Jakarta Press : Jakarta, 2000, hlm. hal 208-209 
Pencantuman hak-hak asasi manusia dalam konstitusi negara Amerika tersebut mendorong pula negara-negara lain untuk mencantumkannya kedalam konstitusi negara mereka. Diantaranya ditahun 1971 semua hak asasi manusia dicantumkan dalam Konstitusi Prancis, kemudian di Belgia pada tahun 1831 dan akhirnya setelah tahun 1948 oleh negara-negara lainnya.

Perkembangan HAM kemudian ditandai dengan kemunculan the american declaration of independence di Amerika Serikat dari semangat paham Rouseau dan Monesqueu. Jadi sekalipun di negara kedua tokoh HAM itu yakni Inggris dan Prancis belum lahir rincian HAM, namun telah muncul di Amerika. Sejak inilah mulai dipertegas bahwa manusia sudah merdeka sejak dalam perut ibunya, sehingga tidaklah masuk akal apabila sesudah lahir ia harus dibelenggu.

Selanjutnya, pada tahun 1789 lahir the french declaration, dimana hak-hak asasi manusia ditetapkan lebih rinci lagi yang kemudian menghasilkan dasar-dasar negara hukum atau the rule of law. Dalam dasar-dasar ini antara lain dinyatakan bahwa tidak boleh terjadi penangkapan dan penahanan yang ssemena-mena, termasuk ditangkap tanpa alasan yang sah atau ditahan tanpa surat perintah, yang dikeluarkan oleh pejabat yang sah. Didalamnya dinyatakan pula asas presumeption of innocence, yaitu bahwa orang-orang yang ditangkap, kemudianditahan dan dituduh, berhak dinyatakan tidak bersalah sampai ada keputusan pengadilan yang berkekuatan hukum tetap menyatakan ia bersalah. Selanjutnya dipertegas juga dengan asas freedom of exspression (kebebasan menganut keyakinan/agama yang dikehendaki), the Righ of property (perlindungan hak milik), dan hak-hak dasar lainnya

Pada mulanya hak asasi manusia terdiri dari hak untuk hidup, hak kemerdekaan pribadi dan hak milik, sebagaimana dikemukakan oleh John Locke di atas. Kemudian pada permulaan perang dunia kedua (1941) Presiden Amerika Serikat Franklin D. Rossevelt menganjurkan untuk mempertahankan hak-hak asasi manusia dari penginjak-injakan tentara nazi Jerman yaitu sebagai berikut :

1. Hak asasi manusia untuk berbicara dan mengeluarkan pendapat.

2. Hak kemerdekaan agama 
3. Hak kebebasan manusia dari ketakutan

4. Hak kebebasan dari kekurangan.

Dalam perkembangan selanjutnya untuk memperjuangkan hak-hak asasi manusia ini terjadilah penandatanganan pernyataan bersama antara kepala-kepala negara barat. Tiga tahun setelah itu pada tanggal 10 Desember 1948 lahirlah Universal Declaration of Human Right. Sedangkan rumusan dari hak-hak asasi manusia itu kami lampirkan pada akhir pembahasan ini.

Beberapa hak-hak asasi manusia yang tercantum pada deklarasi PBB tersebuat adalah :

1. Hak hidup, setiap manusia berhak untuk hidup dan meneruskan kehidupan dangan keturunannya serta mempertahankan kehidupannya itu dengan bebas dan wajar.

2. Hak berpendapat, setiap manusia dalam kalbunya ingin bebas menyatakan pendapatnya menurut jalan pikiran serta pandangan hidupnya tanpa campur tangan dan bebas menerima pendapat orang lain tanpa batasan tertentu.

3. Hak memeluk suatu agama, setiap manusia ingin bebas memeluk suatu agama dan menjalankan ibadahnya sesuai dengan pandangan hidupnya.

4. Hak berserikat dan berkumpul, setiap orang bebas mendapatkan pekerjaan yang sesuai dengan bakat dan kemampuannya untuk memenuhi kebutuhan hidupnya.

5. Hak mendapatkan pekerjaan, setiap orang bebas mendapatkan pekerjaan yang sesuai dengan bakat dan kemampuannya untuk memenuhi kebutuhan hidupnya.

6. Hak mendapatkan pendidikan dan pengajaran, setiap orang memerlukan pendidikan dan pengajaran guna meningkatkan taraf hidupnya.

7. Hak menentukan hari depannya sendiri dan menikmati kehidupan secara wajar dan bebas. Hari depan setiap manusia tidak dapat dipaksakan kepadanya, diberiakn kebebasan untuk menikmati kehidupan ini sesuai dengan keinginannya. 
Inilah diantara hak-hak asasi manusia yang tercantum dalam deklarasi PBB, secara jelas dapat diperhatikan pada lampiran di akhir buku ini. Semenjak hak-hak asasi manusia ini dilahirkan PBB sebagian besar negara-negara di dunia ini memasukannya dlam konstitusi mereka dengan harapan hak-hak asasi manusia itu dapat dijamin oleh hukum dan mendapatkan sanksi hukum bagi yang melanggarnya.

\section{Hak Asasi Manusia Dalam Islam}

Hak asasi manusia dalam Islam telah ada dalam al-Quran dan masyarakat pada zaman nabi Muhammad SAW. ${ }^{8}$ Hak asasi manusia dalam Islam tertuang secara jelas untuk kepentingan manusia, yaitu lewat syari'ah Islam yang diturunkan melalui wahyu.

Menurut syariah, manusia adalah makhluk bebas yang mempunyai tugas dan tanggung jawab, dan karenanya ia juga mempunyai hak dan kebebasan. Dasarnya adalah keadilan yang ditegakkan atas dasar persamaan atau egaliter, tanpa pandang bulu. Artinya, tugas yang diemban tidak akan terwujud tanpa adanya kebebasan, sementara kebebasan secara eksistensial tidak terwujud tanpa adanya tanggung jawab itu sendiri.

Sistem HAM Islam mengandung prinsip-prinsip dasar tentang persamaan, kebebasan dan penghormatan terhadap sesama manusia. Persamaan, artinya Islam memandang semua manusia sama dan mempunyai kedudukan yang sama, satu-satunya keunggulan yang dinikmati seorang manusia atas manusia lainnya hanya ditentukan oleh tingkat ketakwaannya. Al-Qur'an juga menjelaskan 150 ayat tentang ciptaan dan makhluk-makhluk serta tentang persamaan dalam penciptaan.

Hal ini sesuai dengan firman Allah dalam Surat Al-Hujarat ayat 13 :

${ }^{7}$ Drs. Dalizar Putra. Hak Asasi Manusia Menurut Al-Qur'an. Jakarta : Al-Husna Zikra. 1995. Hal 36 hlm. 141

${ }^{8}$ Sidney Hook, dkk. Hak Azazi Manusia dalam Islam. Pustaka Firfdaus, 1987, 


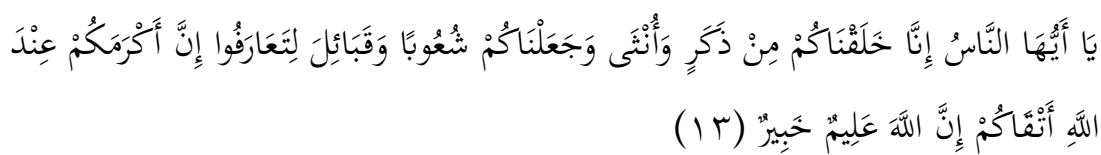

Artinya: "Hai manusia, sesunggubnya Kami ciptakan kamu dari laki-laki dan perempuan, dan Kami jadikan kamu berbangsa-bangsa dan bersuku-suku agar kamu saling mengenal. Sesunggubnya yang paling mulia di antara kaum adalah yang paling takwa."(QS. 49: AlHujurat:13)

Kehadiran Islam memberikan jaminan pada kebebasan manusia agar terhindar dari kesia-siaan dan tekanan, baik yang berkaitan dengan masalah agama, politik dan ideologi. Pada dasarnya HAM dalam Islam terpusat pada lima hal pokok yang terangkum dalam al-dloruriyat al-khomsah atau yang disebut juga al-huquq alinsaniyah fi al-Islam (hak-hak asasi manusia dalam Islam) dan dalam ushul fiqh dikenal dengan Maqashid as- syar'iyah. Konsep itu mengandung lima hal pokok yang harus dijaga oleh setiap individu yaitu hifdzu al-din (penghormatan atas kebebasan beragama), hifdzu almal (penghormatan atas harta benda), bifdzu al-nafs wa al-ird (penghormatan atas jiwa, hak hidup dan kehormatan individu) bifdru al-'aql (penghormatan atas kebebasan berpikir) dan bifdzu al-nasb (keharusan untuk menjaga keturunan). Kelima pokok inilah yang harus dijaga oleh setiap umat Islam supaya menghasilkan tatanan kehidupan yang lebih manusiawi, berdasarkan atas penghormatan individu atas individu, individu dengan masyarakat, masyarakat dengan Negara dan komunitas agama dengan komunitas agama yang lainnya.

Dalam sejarah konstitusi Islam ada dua deklarasi yang memuat hak-hak asasi manusia yang dikenal dengan Piagam Madinah dan Deklarasi Kairo (Cairo Declaration).

a. Piagam Madinah

Konsepsi dasar yang tertuang dalam piagam yang lahir di masa nabi Muhammad SAW adalah adanya pernyataan atau kesepakatan masyarakat Madinah untuk melindungi dan menjamin, hak-hak sesama warga masyarakat tanpa melihat latar belakang,suku, dan agama. Piagam Madinah atau mitsaqul Madianah yang dideklarasikan oleh Rasullullah pada tahun 622 M, merupakan 
kesepakatan tentang aturan yang berlaku bagi masyarakat Madinah yang dipimpin oleh Nabi. Ada dua landasan pokok Piagam Madinah:

1) Semua pemeluk Islam adalah satu umat walaupun mereka berbeda suku bangsa.

2) Hubungan antar komunitas Muslim dan non-muslim didasarkan pada prinsip :

a. Berinteraksi secara baik dengan sesama tetangga

b. Saling membantu dalam menghadapi musuh bersama.

c. Membela mereka yang teraniaya.

d. Saling menasehati.

e. Menghormati kebebasan beragama

b. Deklarasi Kairo (Cairo Declaration)

Konsep ini ditetapkan pada tanggal 5 Agustus 1990 yang mana hak-hak asasi manusia hasil rumusan negara OKI (Organizatian of the Islamic Conference)/ Deklarasi Kairo berisi 24 pasal tentang HAM berdasarkan Al-quran dan Sunnah dan dalam penerapan dan realitasnya memiliki beberapa persamaan dengan pernyataan hak-hak asasi manusia (The Universal Declaration of Human Right/UDHR) yang dideklarasikan oleh PBB tahun 1948. ${ }^{9}$ HAM dalam Islam mempunyai ciri-ciri yaitu sebagai berikut :

1) Bersumber pada ajaran Al-Qur'an dan As-Sunnah

1) Penegakkan HAM tidak boleh bertentangan dengan ajaran syari'at Islam secara komprehensif.

2) Keseimbangan antara hak dan kewajiban

3) Kepentingan sosial ( kebersamaan) diperhatikan

${ }^{9}$ A. Ubaidillah, Abdul Rozak dkk, Pendidikan Kewarganegaraan (Demokrasi, HAM \& Masyarakat Madani).Penerbit IAIN Jakarta Press : Jakarta, 2000, hlm. hal 215216. 
4) Manusia dilihat sebagai makhluk yang dititipi hak-hak dasar oleh Tuhan, dan oleh karena itu mereka wajib mensyukuri dan memeliharanya. ${ }^{10}$

\section{Hak Asasi Manusia menurut al-Quran}

Agama Islam tidak mempunyai piagam khusus untuk Hak Asasi Manusia. Namun al-Quran dan as-Sunnah memberikan perhatian yang sanagt besar terhadap hak-hak asasi manusia. Ayatayat yang memuat tentang hak asasi manusia antara lain:

1) Al-Quran memuat 40 ayat lebih yang menjelaskan tentang paksaan dan kebencian. Ada sekitar10 ayat lebih yang melarang pemaksaan dalam menjamin kebebasan berpikir, berkeyakinan dan mengutarakan aspirasi.

2) Al-Quran menentang kezhaliman dan orang-orang yang berbuat zalim . Terdapat sekitar 320 ayat dan memerintahkan berbuat adil 54 ayat yang diungkapkan dengan kata-kata; 'adl, dan qisth.

3) 80 ayat tentang hidup, pemeliharaan hidup dan penyediaan sarana hidup termuat dalam al-Quran.

4) 150 ayat al- Quran tentang ciptaan dan makhluk serta persamaan penciptaan. ${ }^{11}$

Al-Qur'an sebagai sumber hukum pertama bagi umat Islam telah meletakkan dasar dasar HAM serta kebenaran dan keadilan, jauh sebelum timbul pemikiran mengenai hal tersebut pada masyarakat dunia. Hal ini dapat dilihat ketentuan-ketentuan yang terdapat dalam al-Qur'an, antara lain:

a. Hak Hidup

Hak hidup adalah karunia yang diberikan oleh Allah SWT kepada manusia. Untuk menjamin keberlangsungan hidup dengan tentram dan damai, Islam menerapkan hukum Qishash sebagai balasan untuk pembunuh yang melenyapkan nyawa manusia atau

${ }^{10}$ Kosasih,Ahmad.HAM dalam perspektif ISLAM,Menyingkeap Persamaan dan perbedaan antara Islam dan barat.2003.Jakarta : Salemba Diniyah.hlm. XXVii

${ }^{11}$ Jauhari Abu "Awanah, Islam Menjunjung Tinggi Hak Manusia (Cet. 1; Yogyakarta: Oase Media, 2008), h. 24. 
membuat manusia lainnya cacat. Allah yang memberi manusia hidup dan mati sebagaimana firman Allah dalam Q.S. al-Hijr/15 : 23.

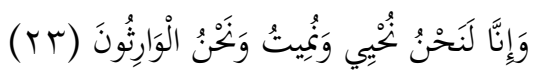

Artinya: "Dan sungguh, Kamilah yang menghidupkan dan mematikan dan Kami (pulalab) yang mewarisi."

Di antara hikmah dipenerapan hukum Qishash dalam pembunuhan adalah untuk menjamin kehidupan manusia yang aman dan tentram sebagaimana. dalam Q.S. al-Baqarah/2 : 179 Allah berfirman:

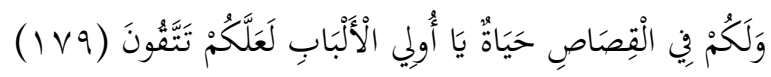

Artinya: "Dan dalam qishas itu ada (jaminan) kehidupan bagimu, wahai orang-orang yang berakal, agar kamu bertakwa".

Hak asasi manusia yang berkaitan dengan kehidupan dalam hal ini hak untuk hidup, menurut Musthafa Husni Assiba'i dalam bukunya "Kehidupan Sosial Menurut Islam Tuntunan Hidup Bermasyarakat" mengatakan bahwa: seluruh syariat Islam yang ada dalam Al-Quran, hadits maupun ijtihad [para imam madzhab, telah memberikan ketentuan mengenai hukum-hukum yang bercabangcabang perihal "Hak Hidup" ini, dan segala sesuatu yang berhubungan dengan cara pemeliharaan kesehatan. ${ }^{12}$

Beberapa contoh hukum-hukum yang ditetapkan yang berhubungan dengan hak hidup, di antaranya:

1) Haram membunuh sesama manusia, di dalam Q.S. AlAn'am/6: 151 .

2) Memberlakukan hukum Qishash dalam pembunuhan: Q.S. Al-Baqarah/2:178.

3) Haram bunuh diri dengan alasan apapun: Q.S. AnNisa'/ 4 : 29.

4) Melarang berspekulasi dengan nyawa. Q.S. Al-Baqarah/2 : 195 .

${ }^{12}$ Musthafa Husni Assiba'i, Kehidupan Sosial Menurut Islam Tuntunan Hidup Bermasyarakat (Cet. 2; Bandung: CV Diponegoro, 1981), h. 69-71 
5) Boleh melakukan peperangan bila diserang musuh: Q.S.Al-Hujarat: 9.

b. Hak untuk merdeka (bebas)

Kemerdekaan adalah hak untuk bebas dari segala bentuk ikatan, perbudakan, dan kekangan merupakan salah satu hak asasi manusia untuk dihargai dan dihormati. Kemerdekaan adalah salah satu cara manusia untuk memperoleh kemuliaan hidup. Menurut Vatin sebagaimana dikutip oleh Harun Nasution mengatakan bahwa: Setiap manusia dilahirkan merdeka. Tidak ada pencabutan bak atas kemerdekaan. Setiap individu mempunyai hak yang tidak terpisabkan atas segala bentuk. kemerdekaan. Oleh karena itu, manusia perlu berjuang dengan segala cara untuk melawan pelanggaran atas pencabutan bak itu. ${ }^{13}$

Dalam al-Quran hak untuk merdeka mencakup beberapa aspek, yaitu:

1. Kemerdekaan kemanusian meliputi; Tidak ada perbudakan dalam Islam: Q.S. al-Mulk/67:23. , Manusia berhak hidup merdeka di tanah airnya: Q.S. al-Haji : 39, Wajib melawan penjajah yang menguasai tanah air denagn semena-mena: Q.S. al-Qashas/28 : 5, dan Wajib membantu bangsa yang ditindas dengan semena-mena oleh penjajah: Q.S. an-Nisa'/4 : 75

2. Kemerdekaan beragama meliputi, Manusia tidak boleh taklid buta dalam memahami agama: Q.S. al-Baqarah/2 : 170, dan Kebebasan dalam beragama. Q.S. al-Baqarah/2 : 256 .

3. Kemerdekaan memperoleh ilmu pengetahuan. Q.S. azZumar:17-18.

4. Kemerdekaan berpolitik. Q.S. Ali Imran/3 : 159.

5. Kemerdekaan sosial

6. Kemerdekaan kemasyarakatan

\footnotetext{
${ }^{13}$ Ahmad Mustafa al-Maraghi, Tafsir al-Maraghi (Cet. 5, jilid 4; Mesir: Musthafa al Babi al Halabi, 1974), h. 71-74
} 
7. Kemerdekaan adabiah (moral). ${ }^{14}$

c. Hak mendapatkan ilmu (pendidikan)

Manusia dilebihkan penciptaannya oleh Allah dengan akal fikiran untuk berfikir. Menurut Quraisy Syihab dalam bukunya "Wawasan al-Quran" mengatakan: bahwa manusia menurut Al-Quran, memiliki potensi untuk memperoleh ilmu dan mengembangkannya seizin Allah. Karena itu, sangat banyak ayat yang memerintahkan manusia menempuh berbagai cara untuk mewujudkan hal tersebut. Menurut pandangan Al-Quran seperti diisyaratkan wahyu pertama ilmu terdiri dari dua macam, pertama; ilmu yang diperoleh tanpa upaya manusia, dinamai ilmu ladunni seperti firman Allah dalam Q.S. Al-Kahfi/18 : 65. kedua, ilmu yang diperoleh karena usaha manusia, dinamai ilmu kasbi. ${ }^{15}$

Firman Allah dalam QS. At- Taubah ayat: 122

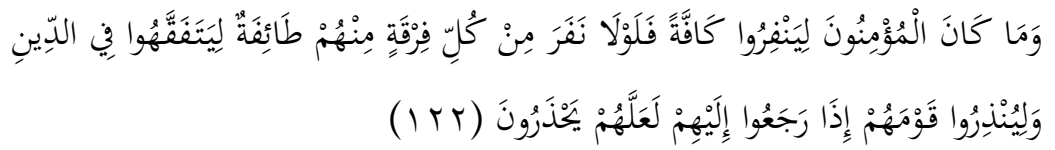

Artinya: "Tidak sepatutnya orang-orang mukmin itu semuanya pergi (ke medan perang). Mengapa sebagian dari golongan di antara mereka tidak pergi untuk untuk memperdalam pengetahuan agama mereka dan untuk memberi peringatan kepada kaumnya jika mereka telah kembali agar mereka itu dapat menjaga dirinya"(QS. AtTaubah:122)

Banyak ayat-ayat di dalam Al-Quran yang berbicara tentang ilmu dan kewajiban mencari ilmu di antaranya adalah Q.S. al'Alaq/96 : 1-5, Q.S. al-Qalam/68 : 1, dan Q.S. at-Thur/52 : 1-3. Di samping itu juga ditemukan dalam hadis-hadis Rasulullah SAW di antaranya yang diriwayatkan oleh at-Tirmidzi; Artinya: Anas ra. Berkata: Rasulullah saw bersabda: "Barangsiapa yang keluar untuk menuntut ilmu maka ia berjuang fisabilillah bingga kembali". ${ }^{16}$

${ }^{14}$ Harun Nasution dan Bahriar Effendy, Hak-Hak Asasi Manusia Dalam Islam (Cet.2; Jakarta: Yayasan Obor Indonesia, 1995), h. 84-104

${ }^{15}$ M.Quraish Shihab, Wawasan Al-Quran (Cet.VI; Bandung: Mizan, 1997), h. 435.

${ }^{16}$ Salim Bahreisy, Tarjamah Riadhus Shalibin II (Cet.2; Bandung: Al-Maarif, 1976), h. 


\section{d. Hak Kehormatan Diri}

Secara asasi setiap manusia mempunyai kehormatan diri. Dapat dikatakan bahwa anugerah terbesar yang diberikan Allah kepada manusia adalah kehormatan diri. Dalam Q.S. al-Isra'/17 : 70 Allah SWT berfirman:

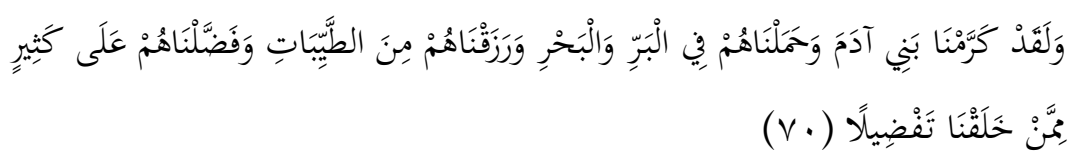

Artinya: "Dan sungguh, Kami telah memuliakan anak cucu Adam dan Kami angkut mereka di darat dan di laut dan Kami beri mereka rižki dari segala yang baik-baik, dan Kami lebibkan mereka di atas banyak makbluk yang Kami ciptakan dengan kelebihan yang sempurna”.

Ayat di atas memberikan ultimatum yang cukup jelas bahwa manusia tidak dapat disangkali menjadi makhluk yang mulia menurut Allah dari sekian banyak jenis makhluk yang ada yang menempati bumi ini. Musthafa Husni Assiba'i juga menulai bahwa: Ayat di atas adalah suatu nash yang jelas dan terang yang menerangkan bahwa manusia adalah semulia-mulia makhluk yang diciptakan Allah SWT di atas permukaan bumi ini. Dijelaskan pula bahwa kemuliaan diri adalah merupakan hak yang utama setiap manusia dan bahwa kemuliaannya itu terjalin menjadi satu dengan sifat kemanusiaan itu sendiri. Oleh sebab itu apabila hak kemuliaan diri itu terhapus atau dihalang-halangi, maka masyarakat yang di situ ia hidup, bukanlah lagi suatu masyarakat yang harmonis, dan bahagia. ${ }^{17}$

Memang hak asasi kehormatan diri tidak berdiri sendiri akan tetapi kemuliaan itu sangat berkaitan erat dengan masyarakat. Setiap individu hidup dalam jenis dan kelompok manusia yang selalu dinamis. Hubungan-hubungan kemanusiaan terjadi sebagai bagian dari kodrat manusia selaku makhluk sosial, dan dalam komunitas kelompok itu kehormatan diri harus terjamin, dijaga dan tidak boleh dilanggar. Pada kelompok manusia juga ditemukan jenis-jenis kemuliaan itu, yaitu:

317.

${ }^{17}$ Musthafa Husni Assiba'i, Kehidupan Sosial Menurut Islam Tuntunan Hidup Bermasyarakat (Cet. 2; Bandung: CV Diponegoro, 1981), h. 133 
1) Kemuliaan persaudaraan sebagai manusia. Q.S. al-Hujarat/49 $: 13$.

2) Kehormatan persamaan hak. Q.S. al-An'am/6:165.

3) Kehormatan keadilan dalam peradilan. Q.S. an-Nisa'/4 : 58

4) Kehormatan keadilan sosial

5) Kehormatan kedudukan dalam masyarakat

6) Kehormatan nama baik keluarga. Q.S. an-Nur/24 : 4-5. ${ }^{18}$

Dengan demikian hak kehormatan diri disandang manusia secara pribadi dan terdapat pula dalam jalinan sosial antar sesama manusia. Artinya, hak kehormatan diri di samping beridi sendiri bersamaan dengan eksistensi manusia, juga dijumpai dalam sistem kehidupan sosial.

\section{Hak Memiliki}

Ketika Islam menetapkan bahwa bagi setiap orang itu harus mempunyai hak hidup, hak kemerdekaan, hak berilmu, hak kehormatan diri dan di waktu Islam menetapkan di samping semuanya itu bahwa segala sesuatu yang ada di alam semesta ini adalah diperuntukkan guna kepentingan seluruh umat manusia sebagaimana difirmankan oleh Allah SWT dalam Q.S. al-Jatsiah/45 : 12-13 sebagai berikut:

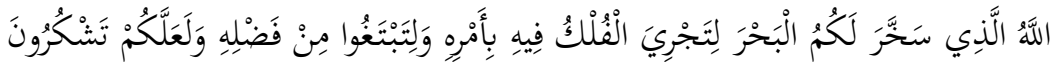

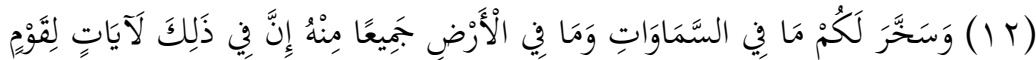

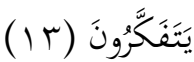

Artinya: Allah-lah yang menundukkean laut untukmu agar kapal-kapal dapat berlayar di atasnya dengan perintah-Nya, dan agar kamu dapat mencari sebagian karunia-Nya, dan agar kamu bersyukur. Dan Dia menundukekan apa yang ada di langit dan apa yang ada di bumi untukmu semuanya (sebagai rabmat) dari-Nya. Sungguh, dalam bal yang demikian itu benar-benra terdapat tanda-tanda (kebesaran Allab) bagi orang-orang yang berpikir.

${ }^{18}$ Ibid, h. 134-136 
Hak memiliki sebagaimana di sebutkan pada ayat di atas bukan berarti hak mutlak yang hanya dimiliki oleh individu tertentu guna memanfaatkan alam yang telah diciptakan Allah, akan tetapi ada suatu sistem yang harus dipatuhi manusia bahwa dalam suasana kehidupan yang merdeka dan terhormat manusia berlomba-lomba bekerja untuk mendapatkan sesuatu tuntuk kelangsungan hidupnya di dunia ini. Pintu pekerjaan di samping dibuka untuk setiap individu juga dibuka untuk semua orang atau dibuka untuk seorang individu dan tidak berarti ditutup untuk sekelompok orang lain. Setiap orang berhak merasakan kesenangan bekerja dalam batas-batas kesanggupannya, keuletannya, kegiatannya dan kecakapannya. Adanya lima hal pokok ini bagi setiap manusia, maka di syariatkan pulalah undang-undang yang dapat menertibkan mengatur setiap macam hak itu, juga untuk menjamin kelancaraan pelaksanaannya bagi setiap warga negara dengan cara yang sempurna mungkin.

Untuk kepentingan itulah, maka dalam Islam timbullah undang-undang pidana dan kesehatan untuk mengatur dan menertibkan hak hidup, undang-undang hukum dan bimbingan sosial dan undang-undang internasionl untuk mengatur hak kemerdekaan, undang-undang pengajaran dan pendidikan untuk mengatur hak berilmu, jugabermacam-macam undang-undang untuk melindungi hak kehormatan diri. Selain itu undang-undang bermuamalat, baik dalam bidang jual beli, pegadaian, persewaan dan lain-lain untuk mengatur hal memiliki ini. Di samping undang-undang untuk melindungi hak tadi, juga disusun pula berangeka ragam bentuk hukuman untuk diterapkan kepada orang-orang yang melanggar atau mempermainkan dari salah satu hak-hak itu.

\section{HAM dan Umat Islam Indonesia}

Implementasi HAM di Indonesia mengikuti iklim politik yang berjalan. Politik di Indonesia bukanlah politik Islam. Namun demikian, dalam banyak hal nilai-nilai Islam masuk ke dalam semangat perundangan dan peraturan negara.Terkait dengan toleransi, kerukunan beragama, dan penolakan terhadap terorisme, umat Islam Indonesia sebagaimana diwakili oleh ormas-ormas Islam (Muhammadiyah, NU, Persis, Al-Irsyad, dan lain-lain) memiliki sikap yang jelas. Umat Islam Indonesia mendukung toleransi, mengutuk terorisme, mengembangkan kebajikan-kebajikan sosial, dan aktif 
dalam program pemberdayaan perempuan dan pengentasan kemiskinan melalui unit-unit organisasi di bawahnya.

Karena itu, melihat umat Islam Indonesia harus dipisahkan dari kebijakan-kebijakan pemerintahnya. Jika ada pelanggaran HAM yang dilakukan oleh negara, maka tidak otomatis oleh umat Islam. Jika ada kekerasan dilakukan oleh oknum umat Islam, tidak otomatis oleh Islam. Pemisahan ini perlu agar segala hal yang tidak sesuai dengan ajaran Islam dianggap sebagai ajaran Islam itu sendiri.

Sikap umat Islam Indonesia terhadap prinsip-prinsip HAM sudah final dan konklusif. Perbedaannya terletak pada aspek rincian dan metode implementasi. Karena itu, kerjasama dan dialog tentang bagaimana menegakkan HAM terus dilakukan dengan mempertimbangkan aspek-aspek spesifik dari masing-masing konsep ajaran agama.

Ormas-ormas Islam adalah representasi dari umat Islam Indonesia. Dalam sejarah HAM, umat Islam justru menjadi korban pelanggaran HAM oleh negara (rezim politik tertentu). Tragedi G 30 S, Peristiwa Tanjung Periuk, dan lain-lainnya adalah contoh pelanggaran HAM yang meminta korban umat Islam. Dengan demikian, selama ini umat Islam Indonesia tetap konsisten membela tegaknya HAM dan bahkan sangat kritis terhadap semua bentuk pelanggaran HAM baik yang dilakukan oleh negara ataupun oleh oknum umat Islam.

Karena itu, menilai apakah Islam di Indonesia bagian dari penegakan HAM harus dilihat dari optik sikap resmi ormas-ormas Islamnya. Bukan oleh sikap pribadi-pribadi Muslim atau kebijakankebijakan pemerintah. Dari perspektif ini hubungan antara umat Islam Indonesia dengan prinsip-prinsip HAM adalah paralel dan bukan antagonistis.

Ormas-ormas Islam Indonesia justru banyak berinisiatif agar akar-akar terorisme dan akar-akar radikalisme Islam disembuhkan dahulu melalui pemberdayaan umat dan pesantren. Pendidikan yang baik dan kesejahteraan yang relatif aman dapat mengurangi umat Islam dari keterlibatan terorisme dan radikalisme.

Di sini, fakta HAM tengah mengalami anti-klimaks di Timur Tengah melalui serangan membabibuta militer Israel atas komunitas 
Gaza. Kini korban-korban konflik Israel-Palestina dengan jumlah yang semakin meningkat setiap harinya (termasuk anak-anak, wanita, dan orang tua) menyuguhkan belum pulihnya tragedi kemanusiaan di zaman modern. Kerjasama global yang selama ini terjalin baik dalam menyelesaikan masalah HAM seperti ternoda dan kehilangan maknanya. Agama-agama harus menjadi spirit perdamaian dan spirit penegakan HAM tanpa batas sehingga menjadi topangan kuat bagi terjalinnya kehidupan manusia yang terlindungi secara HAM.

Dalam konteks keindonesiaan, Hak Asasi Manusia menemukan relevansinya apabila dibangun berdasarkan orientasi maqasid as-syari'ah (tujuan-tujuan dasar syariah), yakni mewujudkan dan menjaga kebaikan serta kemakmuran masyarakat. kepentingan masyarakat, ini kemudian dikenal dengan sebutan mashlahah 'ammah. Maka, HAM dalam perspektif Islam diposisikan sebagai salah satu sistem yang diharapkan mampu membawa manusia untuk hidup lebih baik, tentu dengan memenuhi kewajiban kemanusiaan dan kebutuhan serta menghargai hak-hak orang lain.

\section{Penutup}

Dalam Islam, posisi manusia amat penting dan mulia. Hubungan dengan Allah, alam semesta, dan manusia bahkan menjadi tema utama dalam keseluruhan pembicaraan al-Qur'an. Ini menunjukkan bahwa trikotomi hubungan dengan Allah, alam semesta, dan manusia menempatkan hubungan yang sinergis dan harmonis. Dilihat dari kacamata HAM, trikotomi hubungan itu menunjukan bahwa alam semesta dan manusia harus saling berkerjasama untuk memenuhi sunnatullah dan memperoleh ridha Allah.

Karena itu, nilai-nilai HAM dengan prinsip-prinsipnya yang universal adalah bagian dari semangat dan nilai-nilai Syari'ah. Keduanya tidak perlu dipertentangkan. Keduanya justru membentuk sebuah sinergitas yang harmonis. Dengan menilik potensi-potensi nilai HAM dalam Syari'ah, masa depan HAM di dalam tradisi Islam justru amat cerah dan memperoleh topangan yang amat kuat. Pertumbuhannya akan mengalami gerak naik yang amat menggembirakan. Dibutuhkan pemahaman para ulama yang makin baik tentang sumber-sumber Syari'ah dan wawasan kemodern tentang 
HAM. Dengan wawasan yang luas tentang ini, para ulama akan menjadi avant-guard (garda depan) bagi penegakan HAM berdasarkan Syari'ah dan nilai-nilai universal. 


\section{Daftar Pustaka}

A.Ubaidillah, Abdul Rozak dkk, Pendidikan Kewarganegaraan Demokrasi, $H A M$ \& Masyarakat Madani.Penerbit IAIN Jakarta Press : Jakarta, 2000

al-Maraghi, Ahmad Mustafa., Tafsir al-Maraghi; Mesir: Musthafa al Babi al Halabi, 1974, Cet. 5, jilid 4

Al-Na'im, Abdullah Ahmed., Towards an Islamic Reformation: Civil Liberties, Human Rights and International Law Syracuse: Syracuse University Press, 1990

Assiba'i, Musthafa Husni., Kehidupan Sosial Menurut Islam Tuntunan Hidup Bermasyarakat; Bandung: CV Diponegoro, 1981, Cet. 2

Bahreisy, Salim., Tarjamah Riadhus Shalihin II; Bandung: Al-Maarif, 1976, Cet.2

Bellah, Robert N. (ed.), Beyond Belief (New York: Harper \& Row, edisi paperback, 1976).

H.A.R. Tilaar. Dimensi-dimensi Hak Asasi Manusia dalam Kurikulum Persekolahan Indonesia.PT Alumni, Bandung,

Haikal, Husein. Sirah Nabawiyah , Kairo: Maktabah al-'Arabiyah, 1960.

Kosasih, Ahmad., HAM dalam perspektif ISLAM,Menyingkap Persamaan dan perbedaan antara Islam dan barat. Jakarta : Salemba Diniyah, 2003.

Kuntjoro Purbopranoto. Hak Asasi manusia dan Pancasila. Jakarta : Pradnya paramita. 1976

Louise Marlow, Hierarchy and Egalitarianism in Islamic Thought (Cambridge: Uninersity of Cambridge Press, 1997).

Nasution, Harun., dan Bahriar Effendy, Hak-Hak Asasi Manusia Dalam IslamJ akarta: Yayasan Obor Indonesia, 1995, Cet.2;

Putra, Dalizar., Hak Asasi Manusia Menurut Al-Qur'an. Jakarta : AlHusna Zikra. 1995. 
Qaradhawi, Yusuf. Ghoirul Muslimin fil mujtama' al-Islami Kairo: 1977

Shihab, M. Quraish., Wawasan Al-Quran; Bandung: Mizan, 1997, Cet.VI

Sidney Hook, dkk. Hak Azazi Manusia dalam Islam. Pustaka Firfdaus, 1987

Syaltut, Mahmud., Islam Aqidah wa Syari'abCairo: Dar al-Qalam, 1966 
Hafniati 